\title{
Assessment of Bone Regeneration Using Adipose-Derived Stem Cells in Critical Size Alveolar Ridge Defects: An Experimental Study in a Dog Model
}

\author{
Joaquín Alvira-González, DDS, MS¹/Maria Àngels Sánchez-Garcés, MD, DDS, $\mathrm{PhD}^{2}$ / \\ Joan R. Barbany Cairó, MD, ScB, $\mathrm{PhD}^{3}$ /Manuel Reina del Pozo, $\mathrm{PhD}^{4}$ / \\ Claudia Müller Sánchez, $\mathrm{PhD}^{5} /$ Cosme Gay-Escoda, MD, DDS, MS, $\mathrm{PhD}^{6}$
}

\begin{abstract}
Purpose: To assess bone regeneration potential of a fibronectin- and adipose-derived stem cell-covered ceramic biomaterial in three-wall critical size alveolar ridge defects. Materials and methods: In 18 dogs, four dehiscence-type and critical size defects were created surgically in the edentulous alveolar ridge. Defects were randomly regenerated using biomaterials coated with particulate ß-tricalcium phosphate (ß-TCP), B-TCP with fibronectin (Fn) (B-TCP-Fn), and B-TCP with a combination of Fn and autologous adipose-derived stem cells (ADSCS) (ß-TCP-Fn-ADSCS), leaving one defect as control. The animals were divided into three groups according to the time of euthanasia (1, 2, or 3 months of healing). Results: At the time of sacrifice, statistically significant differences between the four types of defects in the total area of bone regeneration, percentage of neoformed bone matrix, medullary space, or contact between particulate biomaterial and neoformed bone matrix were not found. All defects showed a significant increase in neoformed bone matrix as sacrifice was delayed, but a uniform pattern was not followed. Only defects treated with B-TCP-Fn-ADSCS showed a significant increase in the bone regeneration area when animals sacrificed at 3 months were compared to those sacrificed at 1 month $(P=.006)$. Conclusion: The use of ADSCs in bone regeneration processes of critical size defects of the alveolar ridge did not entail an advantage regarding greater bone regeneration as compared with other biomaterials. However, the use of B-TCP coated with a combination of Fn and ADSCs appeared to favor stabilization of the regenerated area, allowing a more efficient maintenance of the space at 3 months of healing. INT J ORAL MAXILLOFAC IMPLANTS 2016;31:xxx-xxx. doi: 10.11607/4190
\end{abstract}

Key words: adipose-derived stem cells, dehiscence-type defect, fibronectin, guided bone regeneration, stem cells

mplant placement is sometimes limited by critical defects in the edentulous alveolar ridge that occur following traumatic tooth extraction, tooth infections, or postextraction alveolar bone resorption. Large buccal cortical bone defects compromise both placement of implants and esthetic rehabilitation. ${ }^{1}$ Various techniques have been used for restoration of bone defects, including autografts, xenografts, allografts, and alloplasts with and without barrier membranes. Although autogenous bone grafting is accepted as

\footnotetext{
${ }^{1}$ Master Degree Program, Oral Surgery and Implantology, Faculty of Dentistry, University of Barcelona, Spain. [Au: Please provide professional titles for Dr Alvira-González and Dr Sánchez, eg, Professor, Assistant Professor, Researcher, Graduate Student, etc]

${ }^{2}$ Associate Professor of Oral Surgery, Professor, Master Degree Program in Oral Surgery and Implantology, Faculty of Dentistry, University of Barcelona; Researcher,“Fundació Institut d'Investigació Biomedica de Bellvitge" (IDIBELL Institute), L'Hospitalet de Llobregat, Barcelona, Spain.

${ }^{3}$ Full Professor, Human Physiology, Department of Physiological Sciences II, Faculty of Medicine, University of Barcelona, Campus de Bellvitge, Barcelona, Spain.

${ }^{4}$ Associate Professor of Cell Biology, Celltec-UB, Department of Cell Biology, Faculty of Biology, University of Barcelona,
}

Barcelona, Spain.

${ }^{5}$ Celltec-UB, Department of Cell Biology, Faculty of Biology, University of Barcelona, Barcelona, Spain.

${ }^{6}$ Chairman and Professor of Oral and Maxillofacial Surgery, Director of Master Degree Program in Oral Surgery and Implantology, Faculty of Dentistry, University of Barcelona; Coordinator and Researcher,"Fundació Institut d'Investigació Biomedica de Bellvitge" (IDIBELL Institute), L'Hospitalet de Llobregat, and Oral and Maxillofacial Surgery Department, Hospital Quirón Teknon, Barcelona, Spain.

Correspondence to: Dr Cosme Gay-Escoda, Hospital Quirón Teknon, C/ Vilana 12, E-08022 Barcelona, Spain. Fax: +34 93 3933070. Email: cgay@ub.edu 
the gold standard of care, ${ }^{2-7}$ this method is associated with substantial morbidity and is limited in supply. Tissue engineering is a clinical alternative to autogenous bone grafts, and involves the morphogenesis of new tissue using constructs formed from isolated cells with biocompatible scaffolds and growth factors. ${ }^{2,6}$ Bone marrow-derived mesenchymal stem cells (MSCs) have been the main source for bioengineering. However, the clinical use of MSCs has presented problems, including morbidity and low cell number upon harvest. This has led many researchers to investigate alternate sources for MSCs with similar potential to differentiate into lineages of mesenchymal tissue. ${ }^{5,8-13}$

Adipose-derived stem cells may represent a viable alternative option to bone marrow-derived MSCs since both are multipotent (capacity to give rise to a variety of other differentiated cell types, including osteocytes, chondrocytes, adipocytes, and myoblasts) and share common specific cell protein expressions and biomarkers. $8,9,14-19$ Also, bone regeneration may be enhanced by other factors, such as the use of fibronectin. Fibronectin is a glycoprotein of extracellular matrix that favors cell adherence, differentiation, and expansion. The use of biomaterials or titanium surfaces coated with fibronectin has shown satisfactory results in bone regeneration processes and osseointegration of dental implants. ${ }^{20-22}$

The objective of the present experimental study was to assess bone regeneration potential of a ceramic biomaterial (ß-tricalcium phosphate, B-TCP) alone or coated with fibronectin or the combination of fibronectin and adipose-derived stem cells (ADSCs) in three-wall critical size alveolar ridge defects covered with collagen, as compared with a control defect (without biomaterial filling).

\section{MATERIALS AND METHODS}

\section{Material}

The study was approved by the Ethics Committee on Animal Research (CEEA 227-109) of the University of Barcelona. A total of 18 somatically homogeneous female Beagle dogs in which a quarantine period was previously completed were included in the study. Animals were divided into three study groups and sacrificed at 1 (T1), 2 (T2), and 3 (T3) months postoperatively. Each animal was identified with an ear tattoo and microchip implant.

\section{Surgical Protocol}

The surgical protocol was designed into two phases in which animals were submitted to the same anesthetic technique, postoperative analgesia and antibiotic regimens, and aseptic conditions.
Phase 1. The first, second, and third premolars and the first molar of both mandibular hemiarches were extracted under general anesthesia. Dogs were premedicated with acepromazine, $2.5 \mathrm{mg} / 10 \mathrm{~kg}$ subcutaneously (s.c.) (Pharmavet) and atropine sulphate, $0.05 \mathrm{mg} / \mathrm{kg}$ s.c. (John Martin). Anesthesia was induced with sodium thiopental, $10 \mathrm{mg} / \mathrm{kg}$ intravenously (i.v.) (Pentovet, Richmond Vet Pharma) and inhaled 1.5\% to $2 \%$ isoflurane (Sofloran, Pisa Agropecuaria) with subsequent endotracheal intubation. Local anesthetic infiltration, $1.8 \mathrm{~mL}$ per arch (articaine hydrochloride 4\% and epinephrine 1:100,000, Ultracain, Normon) was also administered. Dental extractions were performed by odontosections to ensure preservation of the outer cortical bone, using round burs No. 6 tungsten carbide mounted handpieces and under constant irrigation with sterile saline. Alveolar mucosa was sutured with 4-0 silk sutures on a curved needle (Aragó). Sutures were removed 10 days later.

Phase 2. After a healing period of 3 months, four cylindrical bone defects $(7 \times 7 \times 7 \mathrm{~mm})$ were prepared after elevation of a mucoperiosteal flap, using a trephine bur (7 mm outer diameter), causing complete destruction of the buccal cortical plate of the alveolar ridge. Surgically created critical bone defects were similar to those reported by other authors. ${ }^{23-26}$ The position of the first premolar was assigned to the control group. The three remaining defects were filled at random with (1) 0.25 to $1 \mathrm{~mm}$ of particulate B-TCP (KeraOs, Keramat), (2) particulate B-TCP coated with fibronectin (B-TCP-Fn), and (3) particulate B-TCP coated with a combination of fibronectin and ADSCs (B-TCPFn-ADSCs) (Fig 1). Defects were then covered with $30 \times 40-\mathrm{mm}$ bovine collagen membrane (Bio-Gide, Laboratorios INIBSA), and the surgical field was closed by primary intent with 4-0 silk sutures (Aragó).

Postoperative Care. Animals were kept on a soft diet and treated with amoxicillin trihydrate (Clamoxyl, Pfizer), $15 \mathrm{mg} / \mathrm{kg}$ intramuscularly (i.m.) every 48 hours, starting 24 hours before surgery (five doses, total 10 days) and $0.2 \mathrm{mg} / \mathrm{kg} /$ day of meloxicam (Meloxicam Syntex, Syntex S.A.). Oral hygiene included daily brushing and irrigation with $0.2 \%$ aqueous solution of chlorhexidine.

Animals were sacrificed by a lethal dose of anesthetics at T1, T2, and T3. Both hemi-mandibles were dissected and immersed in $40 \%$ formaldehyde solution in codified containers for histomorphometric analysis.

\section{Bone Histomorphometry}

The samples were processed for study using the technique of embedding in methacrylate described by Donath and Breuner. ${ }^{27} \mathrm{Hemi}$-mandibles were divided into blocks, taking into account the study areas using the Exakt precision cutting and grinding system (Exakt 400 

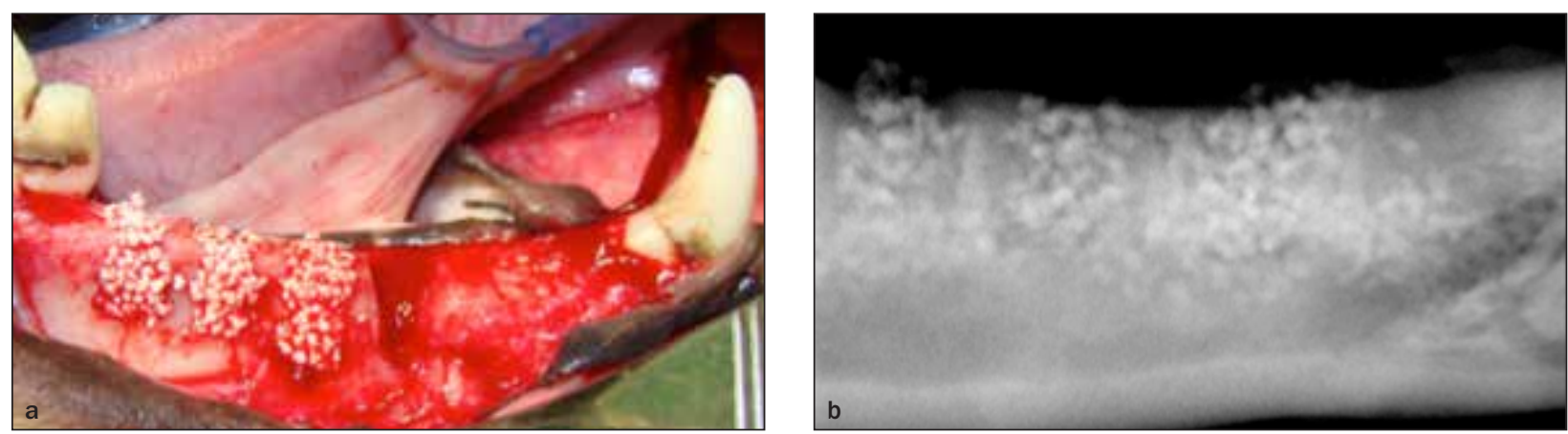

Fig 1 (a) Preoperative view of the three study defects filled at random with bone renegeration biomaterial ( $\beta$-tricalcium phosphate: $\beta$-TCP; $\beta$-TCP with fibronectin [Fn]: $\beta$-TCP-Fn; and $\beta$-TCP with a combination of Fn and adipose-derived stem cells [ADSCs]: $\beta$-TCP-FnADCSs) and unfilled control defect. (b) Periapical radiographic image of the area after 3 months of healing. [Au: Please provide higher resolution images for figure 1.]

System, Apparatebau), dehydrated in graded alcohol, and embedded in glycol methacrylate (Technovit 7200 VLC, Heraeus Kulzer). Blocks were then divided along the long axis, and thickness was reduced until approximately $50-\mu \mathrm{m}$ study samples were obtained.

Samples were stained following the method of Laczko and Levai ${ }^{28}$ [Au: Reference $\mathbf{2 8}$ is Jenö and Géza. Should this be changed?] and were examined under a light microscope (BX51, Olympus) connected to a camera (DP71, Olympus). Twenty-five images at $\times 40$ $(\times 10$ ocular, $\times 4$ objective) were obtained and assembled using the Olympus Cell^D digital image system (Olympus). Reconstructed images were treated with Adobe Photoshop C S3 (Adobe Systems), and the areas of biomaterial and bone neoformation were colored (Fig 2). The following study variables were analyzed using the Microlmage 4.0 software (Olympus): surface area of bone regeneration $\left(\mathrm{mm}^{2}\right)$, percentage of collapsed surface, percentage of neoformed bone matrix, percentage of medullary space, percentage of particulate biomaterial in relation to the original alveolar ridge area (the mean area of the original alveolar ridge was calculated according to the dimensions of the surgically created defect [Fig 3]), total perimeter of the biomaterial, and percentage of the perimeter of biomaterial in contact with the neoformed bone matrix.

\section{Canine Adipose-Derived Stem Cells}

Canine adipose-derived stem cells (cADSCs) were obtained from abdominal subcutaneous adipose tissue following a modified method described by Zuk et al..$^{29}$ Samples (about $5 \mathrm{~g}$ of adipose tissue) were washed intensively with Dulbecco phosphate-buffered saline (DPBS), digested with type I collagenase $(0.16 \mathrm{mg} /$ $\mathrm{mL}$, Sigma) at $37^{\circ} \mathrm{C}$ under shacking for 35 minutes, and centrifuged at $1,200 \mathrm{~g}$ for 10 minutes to separate the stromal cell fraction. The pellets were treated with red cell lysing buffer (KO 2HPO4 $5.7 \mathrm{mmol} / \mathrm{L}, \mathrm{NH} 4 \mathrm{CL}$ $155 \mathrm{mmol} / \mathrm{L}$, and EDTA $0.1 \mathrm{mmol} / \mathrm{L}$ at $\mathrm{pH} 7.23$ ) for 10 minutes at room temperature and centrifuged at 750 $\mathrm{g}$ for 10 minutes. The final pellet was resuspended in CADSCs proliferative medium (PM) consisting of Dulbecco's modified Eagle's medium (Lonza) supplemented with 10\% FBS (Lab Clinic), 2 mmol/L L-glutamine (Lonza), $10 \mathrm{mmol} / \mathrm{L}$ Hepes (Lonza), and antibiotics (Lonza). The cell suspension was filtered through a $100-\mu \mathrm{m}$ mesh (Falcon). Finally, a portion of the CADSCs cells were cryopreserved in cryopreservation medium (90\% FBS-10\% DMSO), frozen at $-80^{\circ} \mathrm{C}$ in an isopropanol-jacketed closed container, and stored in liquid nitrogen the next day. The other portion of the cells were resuspended in PM, plated at $1 \times 10^{5} \mathrm{cells} / \mathrm{cm}^{2}$ in a T75 flask (Nunc) and incubated at $37^{\circ} \mathrm{C}$ in $5 \% \mathrm{CO}_{2}$. After 24 hours, samples were washed with DPBS to eliminate nonadhesive cells and kept in a PM. To obtain a large number of cells, cADSCs were further expanded on polystyrene culture flask with PM at a density of 7.000 cells $/ \mathrm{cm}^{2}$, and the medium changed three times per week. After one passage, when $80 \%$ confluence was achieved, cells were harvested with trypsin-EDTA (Sigma) and used for the characterization experiments.

The isolated cells were seeded at $10.000 \mathrm{cells} / \mathrm{cm}^{2}$ and cultivated 21 days at $37^{\circ} \mathrm{C}$ and $5 \% \mathrm{CO}_{2}$ with $\mathrm{PM}$ or osteogenic medium (OM) consisting of PM supplemented with $50 \mu \mathrm{g} / \mathrm{mL}$ ascorbic acid (Sigma), $1 \mu \mathrm{mol} / \mathrm{L}$ dexamethasone (Sigma) and $10 \mathrm{mmol} / \mathrm{L}$ glycerol $2 \mathrm{P}$ (Sigma). The osteogenesis was demonstrated by accumulation of mineralized calcium phosphate assessed by alizarin red staining.

\section{Coating of $\beta-T C P$ with Fibronectin (Fn) and ADSCs}

Twenty-four hours before the surgery, $500 \mu \mathrm{L}$ of fibronectin solution $(10 \mu \mathrm{g} / \mathrm{mL}$ in DMEM $1 \mathrm{~g} / \mathrm{L})$ was added per gram of bone graft and incubated at $37^{\circ} \mathrm{C}$ for 24 hours. Finally, the coating solution was eliminated, and the grafts were washed with DPBS. One week before the surgery, the cells were thawed and plated at $1 \times 10^{5}$ cells $/ \mathrm{cm}^{2}$ in a T75 flask in PM medium and incubated at $37^{\circ} \mathrm{C}$ in $5 \% \mathrm{CO}_{2}$. After 24 hours, the samples 


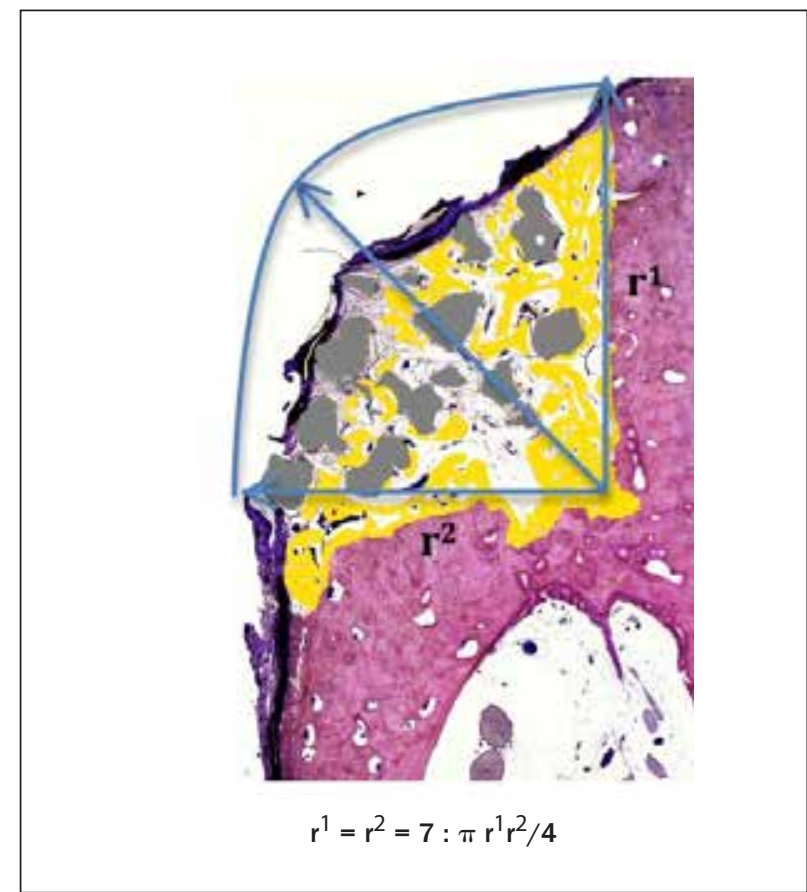

Fig 2 Calculation of the mean area of the original alveolar ridge prior to the surgically created critical defect. [Au: Please provide a higher-resolution image for figure 2.]
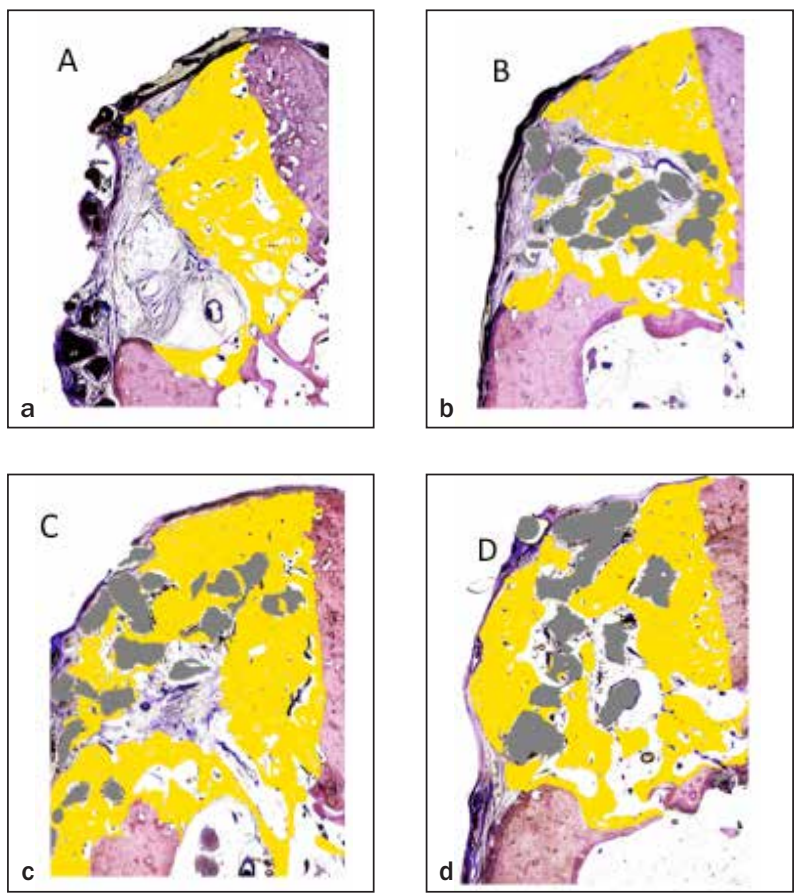

Fig 3. Histologic images of the defects at 3 months of healing treated with the program Microlmage 4.0 software (Olympus). The area of neoformed bone matrix appears in yellow and particulate biomaterial inside the defects in gray. (a) Control. (b) $\beta$-tricalcium phosphate, $\beta$-TCP. (c) $\beta$-TCP with fibronectin: $\beta$-TCPFn. (d) $\beta$-TCP with a combination of fibronectin and adipose-derived stem cells (ADSCs): $\beta$-TCP-Fn-ADCSs. [Au: Please provide higher resolution images for figure 3 without letters.] were washed with DPBS to eliminate nonadhesive cells and kept in a PM. The cells were maintained with PM medium, which was changed three times per week. On the day of surgery, cells were harvested with trypsinEDTA (Sigma) and seeded on $\beta$-TCP bone graft with or without fibronectin coating $\left(5 \times 10^{5}\right.$ cells $/ 1 \mathrm{~g} \beta$-TCP bone graft). To promote the adhesion, the cells seeded on the bone graft were maintained at $37{ }^{\circ} \mathrm{C}$ and $5 \%$ $\mathrm{CO}_{2}$ for 2 hours.

\section{Statistical Analysis}

The Statistical Package for the Social Sciences (SPSS, SPSS Inc) version 15.0 for Windows was used for the analysis of data. Bone histomorphometric variables were expressed as mean and standard deviation (SD). Differences of histomorphometric variables between the control group and the three study groups $(\beta-\mathrm{TCP}$, $\beta$-TCP-Fn, and $\beta$-TCP-Fn-ADSCs) at T1, T2, and T3 were assessed with the analysis of variance (ANOVA), and differences between data at $\mathrm{T} 1, \mathrm{~T} 2$, and $\mathrm{T} 3$ with the $t$ test for paired samples. Statistical significance was set at $P<.05$.

\section{RESULTS}

Of the 18 animals included in the study, two were excluded because of dehiscence of the operated area with important loss of regeneration material. Small wound dehiscence occurred in another two animals, which were sutured immediately, minimizing the loss of biomaterial. Therefore, data from 16 animals were analyzed with four histologic samples for each dog (control, $\beta$-TCP, $\beta$-TCP-Fn, and $\beta$-TCP-Fn-ADSCs), a total of 64 samples, which were grouped according to the euthanasia time (1 month, T1; 2 months, T2; 3 months, T3).

\section{Bone Formation and Degree of Collapse}

As shown in Table 1, there were no statistically significant differences in the mean area of bone regeneration (and, therefore, the percentage of collapsed surface) at $\mathrm{T} 1, \mathrm{~T} 2$, and $\mathrm{T} 3$ time points in all study groups. However, as sacrifice of the animals was delayed, a progressive increase in the bone regeneration area was observed in all groups. Differences were only statistically significant for the group of animals treated with B-TCP-Fn-ADSCs when the bone regeneration area at T3 was compared to T1 (mean [SD] 26.21 [6.22] vs $\left.14.24[4.51] \mathrm{mm}^{2}\right)(P=.006)$.

\section{Neoformed Bone Matrix and Medullary Space}

The percentages of neoformed bone matrix and medullary space in controls and the three study groups at different time points are shown in Table 1. When data 


\begin{tabular}{|c|c|c|c|c|c|}
\hline \multirow[b]{2}{*}{ Data } & \multicolumn{4}{|c|}{ Study groups } & \multirow{2}{*}{$\begin{array}{c}P \\
\text { value }\end{array}$} \\
\hline & Control & $\beta-\mathrm{TCP}$ & $\beta$-TCP-Fn & $\beta$-TCP-Fn-ADSCs & \\
\hline \multicolumn{6}{|c|}{ Bone regeneration area, $\mathrm{mm}^{2}$, mean (SD) } \\
\hline $\mathrm{T} 1$ & $15.62(6.73)$ & $16.77(6.11)$ & $16.32(1.85)$ & $14.24(4.51)^{*}$ & .875 \\
\hline T2 & $18.54(3.78)$ & $19.03(6.28)$ & $21.71(4.44)$ & $19.28(3.47)$ & .708 \\
\hline T3 & $24.23(13.14)$ & $24.55(7.01)$ & $23.78(9.64)$ & $26.21(6.22)^{*}$ & .972 \\
\hline \multicolumn{6}{|c|}{ Collapsed surface, \%, mean (SD) } \\
\hline T1 & $54.41(17.5)$ & $56.41(15.86)$ & $57.58(4.82)$ & 62.98 (11.74) & \\
\hline $\mathrm{T} 2$ & $51.81(9.83)$ & $50.53(16.31)$ & $43.56(11.53)$ & $49.89(9.02)$ & \\
\hline T3 & $37.02(24.15)$ & $36.20(18.21)$ & $38.19(25.05)$ & $31.87(16.18)$ & \\
\hline \multicolumn{6}{|c|}{ Neoformed bone matrix, \%, mean (SD) } \\
\hline T1 & $11.29^{\dagger}(3.42)$ & $14.33^{\dagger}(5.30)$ & $13.03(3.39)$ & $10.08(6.24)$ & .524 \\
\hline T2 & $20.61(6.02)$ & $19.97(7.86)$ & $19.51^{\S}(5.36)$ & $12.33^{\pi}(1.82)$ & .115 \\
\hline T3 & $32.12(15.25)$ & $30.1(4.08)$ & $29.6(11.53)$ & $28.20(6.59)$ & .929 \\
\hline \multicolumn{6}{|c|}{ Medullary space, \%, mean (SD) } \\
\hline $\mathrm{T} 1$ & $22.52(8.75)$ & $20.31(8.01)$ & $21.23(4.92)$ & $18.92(7.69)$ & .891 \\
\hline T2 & $21.63(5.88)$ & $15.94(6.32)$ & $21.17(5.91)$ & $21.87(4.79)$ & .341 \\
\hline T3 & $22.32(18.53)$ & $20.48(7.37)$ & $20.52(11.18)$ & $25.37(9.92)$ & .893 \\
\hline \multicolumn{6}{|c|}{ Biomaterial in contact with neoformed bone matrix, \%, mean (SD) } \\
\hline T1 & NA & $31.43(16.10)$ & $22.78(9.69)$ & $16.50(14.48)$ & .263 \\
\hline T2 & NA & 27.95 (3.49) & $28.71(17.42)$ & $20.03(11.02)$ & .475 \\
\hline T3 & NA & 41.48 (13.63) & 43.95 (21.26) & $27.33(19.73)$ & .275 \\
\hline
\end{tabular}

$\mathrm{NA}=$ not applicable

$* \mathrm{P}=.006 ;{ }^{\dagger} P<.05$ for the comparison of T1 vs T2 and T1 vs T3; ${ }^{\dagger} P<.01$ for the comparison of T1 vs T3; $\$ P<.05$ for the comparison of T2 vs T3; ${ }^{\mathbb{P}} P<.01$ for the comparison of T2 v. T3.

from controls and the three biomaterials ( $\beta$-TCP, $\beta$-TCP$F n$, and $B-T C P-F n-A D S C s$ ) at $\mathrm{T} 1, T 2$, and $\mathrm{T} 3$ euthanasia times were compared, statistically significant differences were not found. However, the percentage of neoformed bone matrix increased significantly in all study groups as sacrifice of the animals was delayed (Table 1).

\section{Biomaterial, Biomaterial Perimeter, and Biomaterial in Contact with Neoformed Bone Matrix}

A total of $81.2 \%(n=13)$ of control defects showed some degree of contamination with particles from the adjacent defects (mean contamination area of 2.69 $\mathrm{mm}^{2}$ accounting for $6.98 \%$ of the bone regeneration area). However, significant differences in the degree of contamination of control defects at the different time points $(T 1, T 2, T 3)$ were not found. Also, the amount of particulate biomaterial was similar in the $\beta$-TCP, $\beta$-TCPFn, and $B$-TCP-Fn-ADSCs groups $(P=.961, P=.824$, and $P=.822$, respectively) and at T1 $(P=.483), \mathrm{T} 2(P=.234)$, and T3 $(P=.217)$ time points. In relation to the total perimeter of biomaterial, similar findings were obtained in the $\beta$-TCP, $\beta-$ TCP-Fn, and B-TCP-Fn-ADSCs groups $(P=.948, P=.901$, and $P=.814$, respectively) and at T1 $(P=.455), \mathrm{T} 2(P=.222)$, and T3 $(P=.182)$ time points.
The percentage of biomaterial in contact with the neoformed bone matrix did not show significant differences considering the type of coating and the euthanasia time (Table 1).

\section{DISCUSSION}

The use of mesenchymal stem cells for regenerative purposes has been shown to be a predictable and promising technique, with reconstruction of critical defects of the arches as the main objective in the field of oral surgery and implantology. ${ }^{2-5}$ Differentiation of mesenchymal stem cells into osteoblasts takes advantage of osteoinduction and osteoconduction properties of autologous bone grafting, avoiding the need to use a donor area and harvesting autogenous bone grafts. 11,19,29,30 More recently, much interest has developed in the use of ADSC, with similar differentiation capabilities to bone marrow cells and the benefits that can be easily harvested and cultured., ${ }^{9,15,19}$ Tissue engineering technology in combination with marrow-derived mesenchymal stem cells have been successfully used for alveolar bone regeneration. ${ }^{32-35}$ [Au: Reference 31 is not cited in the text. Please cite this reference.] Several authors ${ }^{33,36-38}$ underlined the 
favorable results of bone marrow stem cell-scaffold constructs to regenerate bone in significant osseous defects as compared with scaffolds without stem cells, with bone formation indexes similar to those obtained with autografts. ${ }^{37-39}$

However, much controversy exists as to how stem cells efficiently differentiate and regenerate, ${ }^{7-9,17}$ as well as how stem cell origin affects optimal differentiation and regeneration. ${ }^{16,19,40}$ Although ADSCs differentiate directly into osteoblasts less often than do bone marrow stem cells, the total amount of regenerated bone is almost the same. ${ }^{41}$ Moreover, experimental studies support the efficiency of mesenchymal stem cells derived from adipose tissue, periosteum, or umbilical cord blood for regeneration of bone defects. ${ }^{42,43}$

Tissue-engineered bone regeneration using ADSCs provides an acceptable alternative to autologous bone graft, $, 17,40,44$ but the regenerative capacity of ADSCs does not seem to be superior to autologous bone or other bone substitutes in the same conditions, as the authors found in the present study. A combination of B-TCP-Fn-ADSCs was used as a positive control instead of B-TCP-ADSCs because of the limited benefits seen in the results previously obtained by other authors when comparing adipose stem cells alone (or with a scaffold) over other bone substitutes or bone marrow stem cells. ${ }^{45-47}$ In addition, the size of the defects and the space available in the hemi-mandible limited the number of study groups, considering B-TCP-Fn-ADSCs as a more valuable group. The other hemi-mandible was used for another study, whose results will be reported shortly. In a canine maxillary alveolar cleft model, Pourebrahim et $\mathrm{al}^{45}$ showed less bone formation of ADSCs seeded onto hydroxyapatite/ $\beta$-tricalcium phosphate-coated scaffolds than autografts. In the study of reconstruction of rat calvaria defects, Bohnenblust et $\mathrm{al}^{46}$ showed that the presence of osteogenic differentiated adipose stromal cells did not increase overall bone density compared with bone graft only. Han et al, ${ }^{47}$ in cranial defects in rabbits, did not show differences in bone regeneration between ADSCs, demineralized bone matrix (DBM), and the use of ADSCs and DBM together. In the present study, a ceramic biomaterial coated with ADSCs ( $\beta$-TCP-Fn-ADSCs) was not associated with a higher amount of neoformed bone matrix as compared with other particulate biomaterials ( $\beta$-TCP or $\beta$-TCP-Fn) or control defects in each of the $\mathrm{T} 1, \mathrm{~T} 2$, and $\mathrm{T} 3$ study times. However, although there was a significant increase in bone formation as the healing was more advanced, this process was not homogeneous in all groups, with significant increases at 2 months after surgery in controls and at 3 months in $\beta$ TCP and $\beta$-TCP-Fn-ADSCs. The $\beta$-TCP-Fn group showed a progressive increase in neoformed bone matrix, with significant differences between animals sacrificed at 1 and 3 months of healing.

The use of agents as transfer vehicles of stem cells may have a positive effect in the process of bone regeneration of critical defects as well as acting as an osteoconductor element. ${ }^{47}$ Promising experiences have been reported with the combination of stem cells with platelet-rich plasma (PRP), ${ }^{32,48}$ fibrin glue, ${ }^{41,47,49,50}$ polylactic acid (PLA) polymers, ${ }^{51,52}$ synthetic extracellular matrices, ${ }^{53}$ or the use of allogeneic ${ }^{47,54}$ or synthetic ${ }^{33,37}$ bone substitutes. Tricalcium phosphate appears to be a biomaterial of choice for tissue-engineered bone regeneration because of its properties of biocompatibility, high conductivity, and lack of immunogenicity. ${ }^{33,35,37,55,56}$ Although there is insufficient evidence of the ideal biocompatible scaffold, frequently related to the defect size, tricalcium phosphate combined with stem cells has shown satisfactory results in the treatment of bone defects. $33,37,57$

Contamination of control defects with regenerative material from adjacent bone defects, probably due to the use of particulate biomaterial, is a limitation of the study. Khoshzaban et $\mathrm{al}^{57}$ suggested that the material of the experimental defect got transferred to its adjacent empty defect from circulation and animal movement, especially at the operation area, after periosteal approximation. Takahashi et al ${ }^{24}$ concluded that the use of $\beta$-TCP and a collagen sponge could provide better intraoral manipulation capability than TCP granules alone, being particularly indicated in alveolar preservation procedures in bone defects with buccal dehiscence.

Other authors, such as Mankani et $\mathrm{al}_{,}^{56}$ have shown that the size of the particles within bone marrow stromal cells appears to determine the extent of bone formation, with particles of 0.1 to $0.25 \mathrm{~mm}$ size demonstrating the greatest bone formation. In the present study, the use biomaterial of higher particle size (between 0.25 and $1 \mathrm{~mm}$ ) together with a high rate of contamination (80\%) of control defects may be confounding factors for the lack of statistically significant differences in neoformed bone matrix between particulate biomaterial-treated defects ( $\beta$-TCP, $\beta-$ TCP-Fn, and $\beta$-TCP-Fn-ADSCs) and controls.

Fibronectin is an extracellular matrix glycoprotein that promotes cell adhesion, differentiation, and expansion. Jo et a ${ }^{58}$ showed that fibronectin in combination with a xenograft or a ceramic biomaterial (calcium phosphate) have a favorable effect on cell adhesion especially within the first hours after culture. The adhesion-promoting property of fibronectin is particularly relevant in regeneration procedures of bone defects favoring adhesion of stem cells or osteoblasts when combined with some biomaterials. ${ }^{20,51,59,60}$ In the present study, the use of a particulate $\beta$-TCP 
biomaterial coated with fibronectin or a combination of fibronectin and ADSCs was not associated with a better outcome in terms of bone formation or total area of bone regeneration as compared with the other study groups ( $\beta$-TCP alone and controls). However, it should be noted that only bone defects treated with $\beta$-TCP-Fn-ADSCs showed a significant increase in bone regeneration area as the period of the healing process increased. This enhancing effect of fibronectin on bone regeneration processes together with inherent properties of adipose stem cells may contribute to stabilize the regenerated tissue more rapidly, counteracting compression forces of surrounding soft tissue, with a space-maintaining effect that prevents collapse of critical defects. However, given that studies using a similar model of ADSCs have not been previously reported, comparative data are lacking.

\section{CONCLUSIONS}

The use of ADSCs in bone regeneration processes of critical size defects of the alveolar ridge did not entail an advantage regarding greater bone regeneration as compared with other biomaterials. However, the use of $\beta$-TCP coated with a combination of fibronectin and ADSCs appeared to favor stabilization of the regenerated area, allowing a more efficient maintenance of the space at 3 months of healing. The heterogeneity of experimental models in bone regeneration procedures using stem cells of different origins is an important drawback in the assessment of the advantages of the different scaffolds as well as determining the most adequate construct for each type of defect. Further studies are needed to determine the osteogenic ability of ADSCs in the reconstruction of bony defects.

\section{ACKNOWLEDGMENTS}

The authors are indebted to Alvaro Gimeno, MVSc, Head of the Animal Facility at Bellvitge Health Science Campus, University of Barcelona, for his valuable contribution to the care of the experimental animals, and Marta Pulido, MD, for editing the manuscript and editorial assistance. The authors also are grateful to Drs Javier Mir Marí, Lluís Aznar Arasa, and Marwan Nar for their help in both surgical phases of the study. The authors declare that they do not have any conflict of interest. This study was performed by the "Dental and Maxillofacial Pathology and Therapeutic" Research Group of the UB-IDIBELL Institute with the economic support of an educational-clinical agreement in Oral Surgery between the University of Barcelona, General Health Consortium, and the Catalan Health Service of the Autonomous Government of Catalonia. The authors declare no conflicts of interest relate to this study.

\section{REFERENCES}

1. Araújo MG, Lindhe J. Dimensional ridge alterations following tooth extraction. An experimental study in the dog. J Clin Periodontol 2005;32:212-218.

2. Khojasteh A, Behnia H, Dashti SG, Stevens M. Current trends in mesenchymal stem cell application in bone augmentation: A review of the literature. J Oral Maxillofac Surg 2012;70:972-982.

3. Petrovic V, Zivkovic P, Petrovic D, Stefanovic V. Craniofacial bone tissue engineering. Oral Surg Oral Med Oral Pathol Oral Radiol 2012;114:e1-e9.

4. Zaky SH, Cancedda R. Engineering craniofacial structures: Facing the challenge. J Dent Res 2009;88:1077-1091.

5. Machado E, Fernandes MH, Gomes Pde S. Dental stem cells for craniofacial tissue engineering. Oral Surg Oral Med Oral Pathol Oral Radiol 2012;113:728-733.

6. Ward BB, Brown SE, Krebsbach PH. Bioengineering strategies for regeneration of craniofacial bone: A review of emerging technologies. Oral Dis 2010;16:709-716.

7. De Ugarte DA, Alfonso Z, Zuk PA, et al. Differential expression of stem cell mobilization-associated molecules on multi-lineage cells from adipose tissue and bone marrow. Immunol Lett 2003;89:267-270.

8. Hattori H, Sato M, Masuoka K, et al. Osteogenic potential of human adipose tissue-derived stromal cells as an alternative stem cell source. Cells Tissues Organs 2004;178:2-12.

9. Zuk PA, Zhu M, Ashjian P, et al. Human adipose tissue is a source of multipotent stem cells. Mol Biol Cell 2002;13:4279-4295.

10. Soltan M, Smiler D, Soltan C. The inverted periosteal flap: A source of stem cells enhancing bone regeneration. Implant Dent 2009;18:373-379.

11. Ito K, Yamada Y, Nakamura S, Ueda M. Osteogenic potential of effective bone engineering using dental pulp stem cells, bone marrow stem cells, and periosteal cells for osseointegration of dental implants. Int J Oral Maxillofac Implants 2011;26:947-954.

12. Honda MJ, Imaizumi M, Suzuki H, et al. Stem cells isolated from human dental follicles have osteogenic potential. Oral Surg Oral Med Oral Pathol Oral Radiol Endod 2011;111:700-708.

13. Srouji S, Ben-David D, Lotan R, et al. The innate osteogenic potential of the maxillary sinus (Schneiderian) membrane: An ectopic tissue transplant model simulating sinus lifting. Int J Oral Maxillofac Surg 2010;39:793-801.

14. Zuk PA. Adipose-derived stem cells in tissue regeneration: A review. ISRN Stem Cells 2013: 713959. doi:10.1155/2013/713959.

15. Zhu Y, Liu T, Song K, et al. Adipose-derived stem cell: A better stem cell than BMSC. Cell Biochem Funct 2008;26:664-675.

16. Im Gl, Shin YW, Lee KB. Do adipose tissue-derived mesenchymal stem cells have the same osteogenic and chondrogenic potential as bone marrow-derived cells? Osteoarthritis Cartilage 2005;13:845-853.

17. De Ugarte DA, Morizono K, Elbarbary A, et al. Comparison of multi lineage cells from human adipose tissue and bone marrow. Cells Tissues Organs 2003;174:101-109.

18. Barba M, Cicione C, Bernardini C, Michetti F, Lattanzi W. Adiposederived mesenchymal cells for bone regeneration: State of the art. Biomed Res Int 2013:416391. doi: 10.1155/2013/416391. [Epub ahead of print]

19. Hayashi O, Katsube Y, Hirose M, Ohgushi H, Ito H. Comparison of osteogenic ability of rat mesenchymal stem cells from bone marrow, periosteum, and adipose tissue. Calcif Tissue Int 2008;82:238-247.

20. Park JM, Koak JY, Jang JH, et al. Osseointegration of anodized titanium implants coated with fibroblast growth factor-fibronectin (FGF-FN) fusion protein. Int J Oral Maxillofac Implants 2005;21:859866.

21. Rivera-Chacon DM, Alvarado-Velez M, Acevedo-Morantes CY, et al. Fibronectin and vitronectin promote human fetal osteoblast cell attachment and proliferation on nanoporous titanium surfaces. J Biomed Nanotechnol 2013;9:1092-1097.

22. Rapuano BE, Hackshaw KM, Schniepp HC, MacDonald DE. Effects of coating a titanium alloy with fibronectin on the expression of osteoblast gene markers in the MC3T3 osteoprogenitor cell line. Int J Oral Maxillofac Implants 2012;27:1081-1090. 
23. von Arx T, Cochran DL, Hermann JS, Schenk RK, Buser D. Lateral ridge augmentation using different bone fillers and barrier membrane application. A histologic and histomorphometric pilot study in the canine mandible. Clin Oral Implants Res 2001;12:260-269.

24. Takahashi Y, Marukawa E, Omura K. Application of a new material ( $\beta$-TCP/Collagen Composites) in extraction socket preservation: An experimental study in dogs. Int J Oral Maxillofac Implants 2013;28:444-452.

25. Lee JS, Ko SH, Kim YT, Jung UW, Choi SH. Guided bone regeneration using cyanoacrylate-combined calcium phosphate in a dehiscence defect: A histologic study in dogs. J Oral Maxillofac Surg 2012;70:2070-2079.

26. Li X, Wang X, Zhao T, et al. Guided bone regeneration using chitosan-collagen membranes in dog dehiscence-type defect model. J Oral Maxillofac Surg 2014;72:1-14.

27. Donath K, Breuner G. A method for the study of undecalcified bones and teeth with attached soft tissues. The Säge-Schliff (sawing and grinding) technique. J Oral Pathol Med 1982;11:318-326.

28. Jenö L, Géza L. A simple differential staining method for semi-thin sections of ossifying cartilage and bone tissues embedded in epoxy resin. Mikroskopie 1975;31:1-4.

29. Zuk PA, Zhu M, Mizuno $H$, et al. Multilineage cells from human adipose tissue: Implications for cell-based therapies. Tissue Eng 2001;7:211-228.

30. Robey PG, Bianco P. The use of adult stem cells in rebuilding the human face. J Am Dent Assoc 2006;137:961-972.

31. Handschel J, Naujoks C, Depprich R, et al. Embryonic stem cells in scaffold-free three-dimensional cell culture: Osteogenic differentiation and bone generation. Head Face Med 2011;7:12.

32. Yamada Y, Ueda M, Hibi H, Nagasaka T. Translational research for injectable tissue-engineered bone regeneration using mesenchymal stem cells and platelet-rich plasma: From basic research to clinical case study. Cell Transplant 2004;13:343-355.

33. Jafarian M, Eslaminejad MB, Khojasteh A, et al. Marrow-derived mesenchymal stem cells-directed bone regeneration in the dog mandible: A comparison between biphasic calcium phosphate and natural bone mineral. Oral Surg Oral Med Oral Pathol Oral Radiol Endod 2008;105:14-24.

34. De Kok IJ, Peter SJ, Archambault M, et al. Investigation of allogeneic mesenchymal stem cell-based alveolar bone formation: Preliminary findings. Clin Oral Implants Res 2003;14:481-489.

35. De Kok IJ, Drapeau SJ, Young R, Cooper LF. Evaluation of mesenchymal stem cells following implantation in alveolar sockets: A canine safety study. Int J Oral Maxillofac Implants 2005;20:511-518.

36. Ito K, Yamada Y, Naiki T, Ueda M. Simultaneous implant placement and bone regeneration around dental implants using tissueengineered bone with fibrin glue, mesenchymal stem cells and platelet-rich plasma. Clin Oral Implants Res 2006;17:579-586.

37. Yuan J, Cui L, Zhang WJ, Liu W, Cao Y. Repair of canine mandibular bone defects with bone marrow stromal cells and porous betatricalcium phosphate. Biomaterials 2007;28:1005-1013.

38. Khojasteh A, Eslaminejad MB, Nazarian H. Mesenchymal stem cells enhance bone regeneration in rat calvarial critical size defects more than platelete-rich plasma. Oral Surg Oral Med Oral Pathol Oral Radiol Endod 2008;106:356-362.

39. Yamada Y, Ueda M, Naiki T, et al. Autogenous injectable bone for regeneration with mesenchymal stem cells and platelet-rich plasma: Tissue-engineered bone regeneration. Tissue Eng 2004;10:955-964.

40. Zaminy A, Ragerdi Kashani I, Barbarestani M, et al. Osteogenic differentiation of rat mesenchymal stem cells from adipose tissue in comparison with bone marrow mesenchymal stem cells: Melatonin as a differentiation factor. Iran Biomed J 2008;12:133-141.

41. Han DS, Chang HK, Kim KR, Woo SM. Consideration of bone regeneration effect of stem cells: Comparison of bone regeneration between bone marrow stem cells and adipose-derived stem cells. J Craniofac Surg 2014;25:196-201.

42. Stockmann P, Park J, von Wilmowsky C, et al. Guided bone regeneration in pig calvarial bone defects using autologous mesenchymal stem/progenitor cells-a comparison of different tissue sources. J Craniomaxillofac Surg 2012;40:310-320.
43. Kang BJ, Ryu HH, Park SS, et al. Comparing the osteogenic potential of canine mesenchymal stem cells derived from adipose tissues, bone marrow, umbilical cord blood, and Wharton's jelly for treating bone defects. J Vet Sci 2012;13:299-310.

44. Streckbein $P$, Jäckel S, Malik CY, et al. Reconstruction of criticalsize mandibular defects in immunoincompetent rats with human adipose-derived stromal cells. J Craniomaxillofac Surg 2013;41:496-503.

45. Pourebrahim N, Hashemibeni B, Shahnaseri S, et al. A comparison of tissue-engineered bone from adipose-derived stem cell with autogenous bone repair in maxillary alveolar cleft model in dogs. J Oral Maxillofac Surg 2013;42:562-568.

46. Bohnenblust ME, Steigelman MB, Wang Q, Walker JA, Wang HT. An experimental design to study adipocyte stem cells for reconstruction of calvarial defects. J Craniofac Surg 2009;20:340-346.

47. Han DS, Chang HK, Park JH, Kim KR, Woo SM. Consideration of bone regeneration effect of stem cells: Comparison between adiposederived stem cells and demineralized bone matrix. J Craniofac Surg 2014;25:189-195.

48. Yamada Y, Ueda M, Naiki T, Nagasaka T. Tissue-engineered injectable bone regeneration for osseointegrated dental implants. Clin Oral Implants Res 2004;15:589-597.

49. Hayashi O, Katsube $Y$, Hirose M, Ohgushi $H$, Ito H. Comparison of osteogenic ability of rat mesenchymal stem cells from bone marrow, periosteum, and adipose tissue. Calcif Tissue Int 2008;82:238-247.

50. Lee LT, Kwan PC, Chen YF, Wong YK. Comparison of the effectiveness of autologous fibrin glue and macroporous biphasic calcium phosphate as carriers in the osteogenesis process with or without mesenchymal stem cells. J Chin Med Assoc 2008;71:66-73.

51. Di Bella C, Farlie P, Penington AJ. Bone regeneration in a rabbit critical-sized skull defect using autologous adipose-derived cells. Tissue Eng Part A 2008;14:483-490.

52. El-Amin SF, Lu HH, Khan Y, et al. Extracellular matrix production by human osteoblasts cultured on biodegradable polymers applicable for tissue engineering. Biomaterials 2003;24:1213-1221.

53. Yoshimi R, Yamada Y, Ito K, et al. Self-assembling peptide nanofiber scaffolds, platelet-rich plasma, and mesenchymal stem cells for injectable bone regeneration with tissue engineering. J Craniofac Surg 2009;20:1523-1530.

54. Cornejo A, Sahar DE, Stephenson SM, et al. Effect of adipose tissue-derived osteogenic and endothelial cells on bone allograft osteogenesis and vascularization in critical-sized calvarial defects. Tissue Eng Part A 2012;18:1552-1561.

55. Bose S, Tarafder S. Calcium phosphate ceramic systems in growth factor and drug delivery for bone tissue engineering: A review. Acta Biomater 2012;8:1401-1421.

56. Mankani MH, Kuznetsov SA, Fowler B, Kingman A, Robey PG. In vivo bone formation by human bone marrow stromal cells: Effect of carrier particle size and shape. Biotechnol Bioeng 2001;72:96-107.

57. Khoshzaban A, Mehrzad S, Tavakoli V, et al. The comparative effectiveness of demineralized bone matrix, beta-tricalcium phosphate, and bovine-derived anorganic bone matrix on inflammation and bone formation using a paired calvarial defect model in rats. Clin Cosmet Investig Dent 2011;3:69-78.

58. Jo YJ, Kim KH, Koo KT, et al. Initial adhesion of bone marrow stroma cells to various bone graft substitutes. J Periodontal Implant Sci 2011:41:67-72.

59. Bruder SP, Kurth AA, Shea M, et al. Bone regeneration by implantation of purified, culture-expanded human mesenchymal stem cells. J Orthop Res 1998;16:155-162.

60. Lee SJ, Lim GJ, Lee JW, Atala A, Yoo JJ. In vitro evaluation of a poly(lactide-co-glycolide)-collagen composite scaffold for bone regeneration. Biomaterials 2006;27:3466-3472. 